\title{
ANALYSIS OF THE RELATIONSHIP BETWEEN MICROBIAL ACTIVITIES IN HUMUS SOIL TOWARDS INFILTRATION RATE FOR FERTILITY IMPROVEMENT WITH BIOSOILDAM TECHNOLOGY FOR CORN PLANTATION
}

\section{Nugroho Widiasmadi}

Faculty of Engineering, Wahid Hasyim Universitas, Semarang, Jawa Tengah, Indonesia Email: nugrohowidiasmadi@unwahas.ac.id

\begin{abstract}
This research was conducted on Humus soils, especially for Corn Plantation, aimed at restoring soil health and fertility due to the use of chemical fertilizers and pesticides. Through controlled microbial activity through bio whole. This study observes periodically changes in soil acidity, infiltration rate, and electrolyte conductivity levels around the center of the biohole as the center of the microbial distribution. As a comparison, observations were made using a biohole that was only filled with water without microbes. Furthermore, these two conditions, namely biohole with microbes and biohole without microbes, were compared to changes in parameters: soil acidity, infiltration rate, and electrolyte conductivity levels. So that it can be seen a real difference in the speed of improvement of the two soil conditions and the ability of the soil to provide nutrients during vegetative and generative growth. Soil carrying capacity research using microbial activity variables as a measurable control is called Biosoildam Technology. This research was conducted on agricultural land with commodities as above. The tools used are the Double Ring Infiltrometer to measure the infiltration rate at three radial distances from the center of the microbial hole (Biohole), the measurement of electrolyte salt content as an indication of soil fertility using Electrolyte Conductivity, and the use of a PH meter as a measure of soil acidity. Infiltration calculations were carried out every 5 minutes and observed every 15 days for 45 days. This research is expected to: reduce production costs, increase crop yields, make agriculture sustainable, produce multiplayer economies of effect, strengthen crops to face global climate change. The result of the research shows that the highest infiltration rate, infiltration capacity, fertility \& acidity happened on soil involving Biofertilizer MA-11, ie 83-99 cm/hour, $325-970 \mathrm{uS} / \mathrm{cm}, \mathrm{PH}=6-6,5$. While the lowest infiltration rate, infiltration capacity, fertility \& acidity was happened on soil without involving Alfaafa Microba MA-11, ie 31- $52 \mathrm{~cm} /$ hour, $325-540 \mathrm{uS} / \mathrm{cm}$, PH $5-6$
\end{abstract}

Keywords: humus; biohole; infiltration; biosolid; land use; Alfalfa Microba; fertility; acidity

\section{Introduction}

One of the main contributing factors is a decrease in fertility, health, and soil absorption (infiltration rate) triggered by excessive use of inorganic fertilizers

$\begin{array}{ll}\text { How to cite: } & \text { Widiasmadi. N (2021) Analysis of The Relationship Between Microbial Activities In Humus Soil Towards } \\ & \text { Infiltration Rate for Fertility Improvement With Biosoildam Technology for Corn Plantation. Syntax Literate: } \\ & \text { Jurnal Ilmiah Indonesia, 6(10). http://dx.doi.org/10.36418/ Syntax-Literate.v6i10.4371 } \\ \text { E-ISSN: } & 2548-1398 \\ \text { Published by: } & \text { Ridwan Institute }\end{array}$


(pesticides) (Widiasmadi, 2019), the ecological function of absorbing rainwater RTH is an area planted with trees and grass that can improve soil structure so that the rate of rainwater infiltration can be maintained (Budi, 2016). The place is around reservoirs or lakes that can minimize water runoff on the surface when it rains (Rochim \& Syahbana, 2013). According to (Yohana, Griandini, \& Muzambeq, 2017), one of the environmentally friendly technological solutions in overcoming the availability of groundwater is by making bio pure infiltration holes, namely technological engineering for water absorption in the form of vertical and effective cylindrical holes (Martha, 2018), and according to LRB also by impregnating and reducing the overflow of rainwater can minimize the occurrence of flooding (Latifah, 2012). In addition, according to (Widyastuti, 2013), one method to reduce the accumulation of organic waste is to turn it into compost. However, according to (Santosa, 2018), fruit waste causes a higher water infiltration rate than vegetable or leaf waste. Infiltration is the process of water flowing into the soil which generally comes from rainfall, while the infiltration rate is the amount of water that enters the soil per unit of time. This process is a very important part of the hydrological cycle which can affect the amount of water that is on the surface of the soil. Water on the surface soil will enter the soil and then flow into the river (Sunjoto, 2011). Not all surface water flows into the soil, but some portion of the water remains in topsoil to be further evaporated back into the atmosphere through the soil surface or soil evaporation (Eng \& Dr, 2004).

Infiltration capacity is the ability of the soil to absorb large amounts of water into the ground and is influenced by the microorganism activities in the soil (Nugroho Widiasmadi, 2020). The large infiltration capacity can reduce surface runoff. The reduced soil pores, generally caused by soil compacting, can cause a decreased infiltration. This condition is also affected by soil contamination (Dr, 2020) due to excessive use of chemical fertilizers and pesticides which hardens the soil as well.

Biosoildam is a Biodam technology that involves microbial activity in increasing the measured and controlled inflation rate. Biological activities through the role of microbes as agents of biomass decomposition and soil conservation become important information for soil conservation efforts in supporting healthy food security.

Increased soil friability by involving microbial activities (Bioinfiltrosoil) can be used as the development of the science of Civil Hidro Engineering as Eco-Civil Engineering. So that engineering can provide value to the carrying capacity of land productivity through soil and water conservation (Widiasmadi, 2019).

\section{Method}

The study was conducted on Humus land which for decades has been the source of livelihood for the community of Legundi Village Karangjati District Ngawi Regency. Land management lacks soil and water conservation. People use chemical fertilizers \& pesticides excessively which harden the soil texture, acidify the soil and decrease the yields. Hardened agricultural land also triggers floods, since the soil's ability to absorb decreases. This research that took place from Augustus to December 
Analysis of The Relationship Between Microbial Activities In Humus Soil Towards Infiltration Rate for Fertility Improvement With Biosoildam Technology for Corn

Plantation

2018 , intends to restore the carrying capacity of the land.

Tools and materials used in research are Biohole as Biosoildam Injector, microbial decomposer Alfafaa MA-11, red onion straw as a microbial nest, Abney level, measuring tape, Double Ring Infiltrometer, stirring rod, Erlenmeyer, ruler, Stopwatch/watch, bucket plastic, tally sheet, measuring cup, scales, hydrometers, and water (Douglas, 2018).

1. Determining plot and sensor points

To determine plots and sensors, this study uses purposive sampling at various distances: $0.5 ; 1,0 ; 1,5$ meters from the center of Biohole with a diameter of 1 meter as the central radial distribution of the biological agent Microbe Alfaafa MA-11 through the water injection process. Infiltration rate and radial biological agent distribution can be controlled measurement sensors with parameters: EC/salt ion (macronutrients), $\mathrm{pH}$, the infiltration rate with a Double Ring Infiltrometer on the variable distance from the center of the Biohole are manually measured. Next, soil samples are also taken to analyze their characteristics, such as soil texture, organic material content, and bulk density (Douglas, 2018).

\section{RADIUS PENEMPATAN DOUBLE RING INFILTROMETER TERHADAP BIOHOLE}

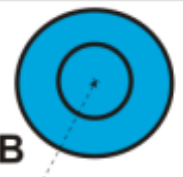

$\mathrm{m}$

Electrolit Conductivity Meter $\mathrm{PH}$ Merer

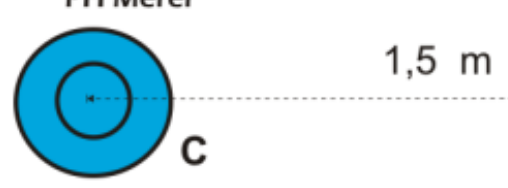

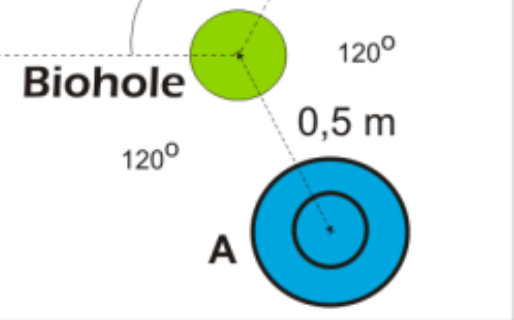

\section{Figure 1 \\ Double Ring Infiltrometer setting}

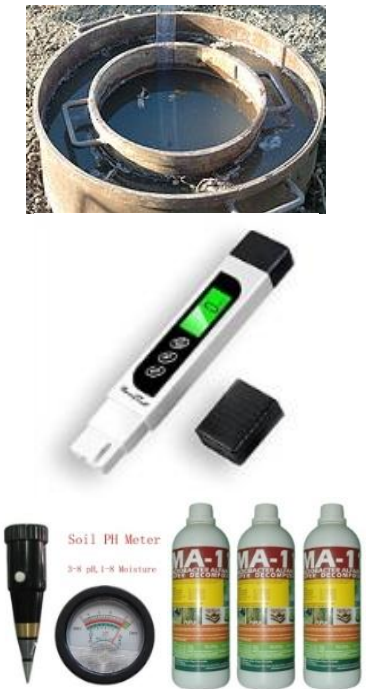



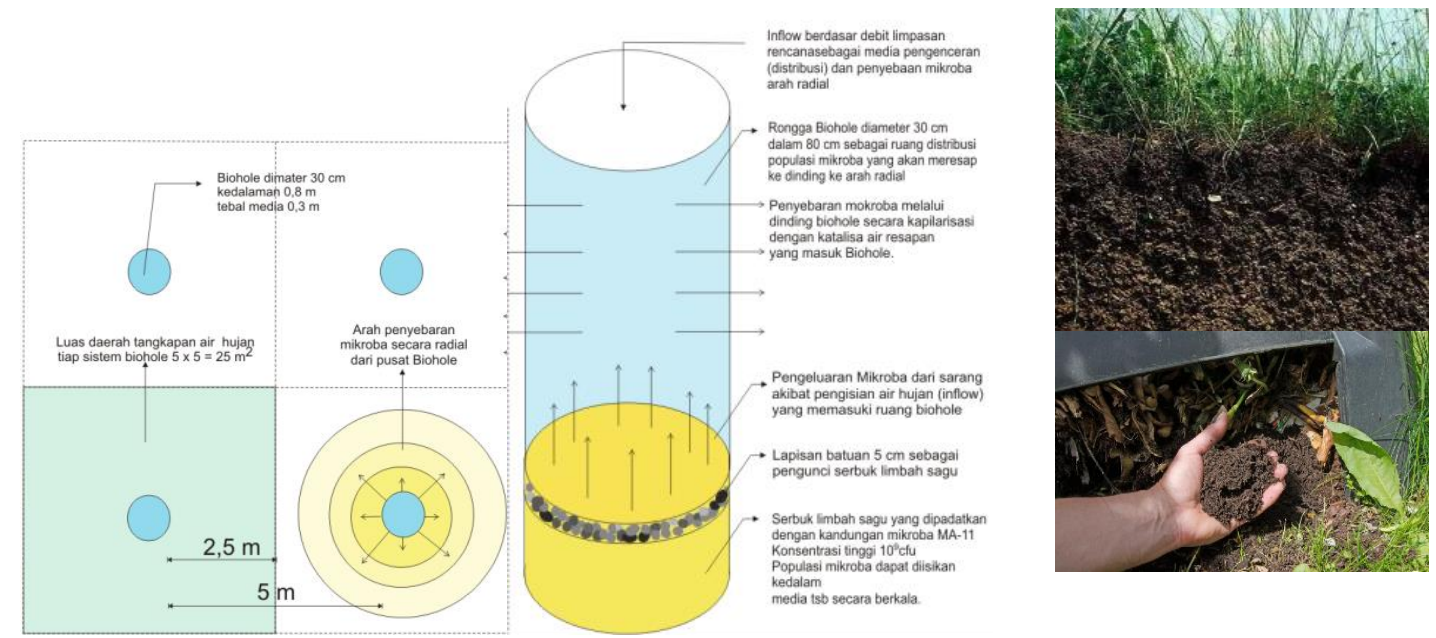

Figure 2

Distribution biohole -Biohole Structure \& Humus Land

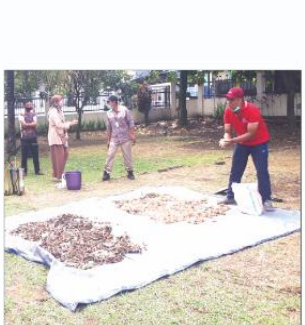

Microbial Nest Decomposting
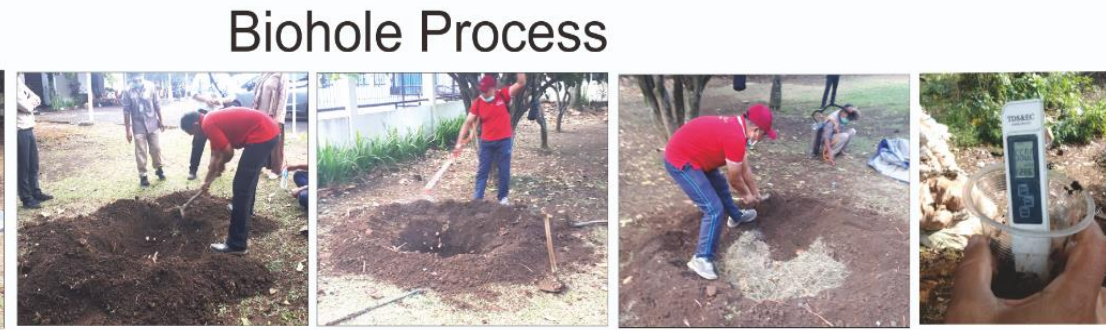

Diging

Oxygen Supply Microbial Nest Fill

Electrolit Cond.

Figure 3

Biohole Process
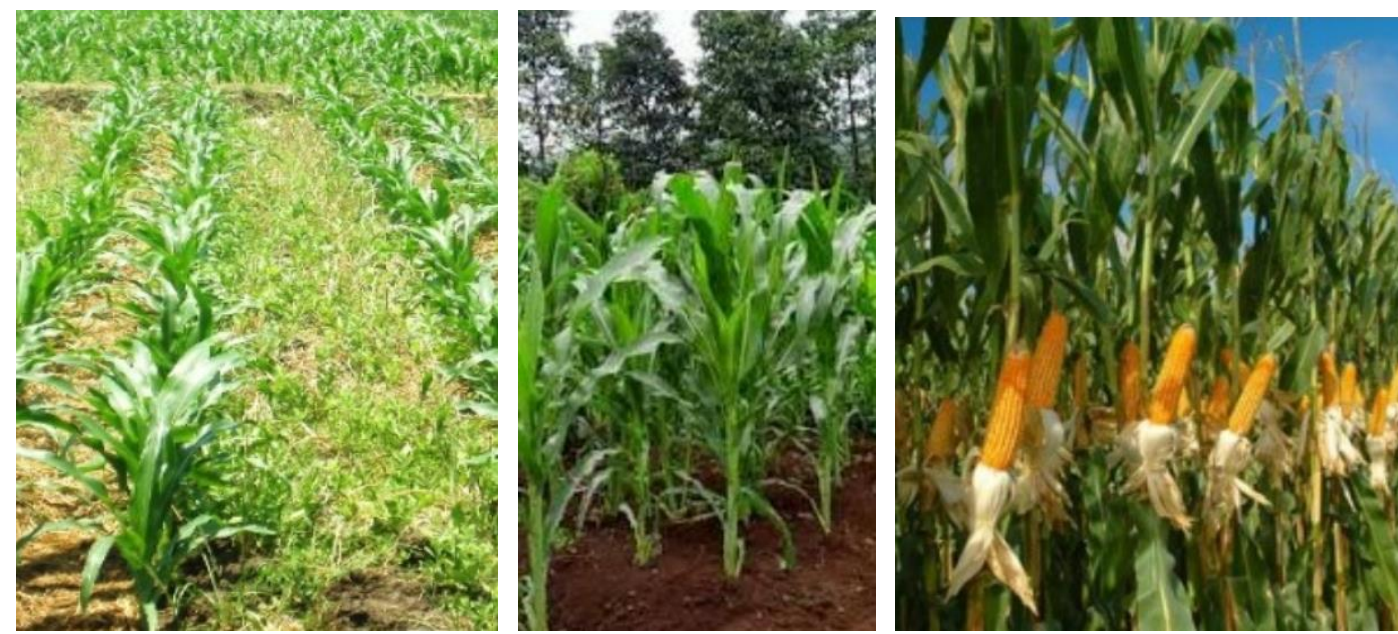

Figure 4

Corn Plantation

2. Data Processing

a. Catalytic Discharge 
Analysis of The Relationship Between Microbial Activities In Humus Soil Towards Infiltration Rate for Fertility Improvement With Biosoildam Technology for Corn

Plantation

Biosoildam innovation uses runoff discharge as a media for biological agents distribution through the inlet/inflow (Biohole) as a center for the microbial population's distribution with water. The runoff discharge calculation as a basis for the Inflow Biosoildam formula requires the following stages:

1. conducting a rainfall analysis,

2. calculating the catchment area, and

3. analyzing the soil/rock layers.

Biosoildam structure can be made with holes in the soil layer without or using water pipes/reinforced concrete pipes (RCP) with a perforated layer that will let microbes spread radially. We can calculate the discharge entering Biohole as a function of the catchment characteristic with a rational formula:

$\mathrm{Q}=0,278$ CIA

where $\mathrm{C}$ is the runoff coefficient value, $\mathrm{I}$ is the precipitation and $\mathrm{A}$ is the area (Sunjoto, 2011). Based on this formula, the Table presents the results of runoff discharge.

b. Infiltration

Infiltration is the process by which water on the ground surface enters the soil. It is commonly used in both hydrology and soil sciences. The infiltration capacity is defined as the maximum rate of infiltration. It is most often measured in meters per day but can also be measured in other units of distance overtime if necessary. The infiltration capacity decreases as the soil moisture content of soils surface layers increases. If the precipitation rate exceeds the infiltration rate, a runoff will usually occur unless there is some physical barrier. Infiltrometers, parameters, and rainfall simulators are all devices that can be used to measure infiltration rates. Infiltration is caused by multiple factors including; gravity, capillary forces, adsorption, and osmosis. Many soil characteristics can also play a role in determining the rate at which infiltration occurs.

The spread of microbes as a biomass decomposing agent can be controlled through the calculation of the infiltration rate at several point radii from Biohole as the center of the spread of microbes. by using the Horton method. Horton observed that infiltration starts from a standard value fo and exponentially decreases to a constant condition FC. One of the earliest infiltration equations developed by Horton is:

$$
f(t)=F C+\left(f_{o}-F C\right) e^{-k t}
$$

where :

$\mathrm{k}$ is a constant reduction to the dimension [ $\mathrm{T}-1]$ or a constant decreasing infiltration rate.

fo is an infiltration rate capacity at the beginning of the measurement.

FC is a constant infiltration capacity that depends on the soil type. 
The fo and FC parameters are obtained from the field measurement using a double-ring infiltrometer. The fo and FC parameters are the functions of soil type and cover. Sandy or gravel soils have high values, while bare clay soils have little value, and for grassy land surfaces, the value increases (Sutanto, 2012).

The infiltration calculation data from the measurement results in the first 15 minutes, the second 15 minutes, the third 15 minutes, and the fourth 15 minutes at each distance from the center of Biohole are converted in units of $\mathrm{cm} / \mathrm{hour}$ with the following formula:

Infiltration rate $=(\Delta \mathrm{H} / \mathrm{t} \times 60)$

where:

$\Delta \mathrm{H}=$ height decrease $(\mathrm{cm})$ within a certain time interval,

$\mathrm{T}=$ the time interval required by water in $\Delta \mathrm{H}$ to enter the ground (minutes) (Zhanbin, Lun, Suiqi, \& Pute, 1997). This observation takes place every 3 days for one month.

c. Soil Characteristics

The porosity of soils is critical in determining the infiltration capacity. Soils that have smaller pore sizes, such as clay, have lower infiltration capacity and slower infiltration rates than soils that have large pore sizes, such as sands. One exception to this rule is when the clay is present in dry conditions. In this case, the soil can develop large cracks which lead to higher infiltration capacity.

Soil compaction is also impacted infiltration capacity. Compaction of soils results in decreased porosity within the soils, which decreases infiltration capacity.

Hydrophobic soils can develop after wildfires have happened, which can greatly diminish or completely prevent infiltration from occurring.

Soil moisture content: Soil that is already saturated has no more capacity to hold more water, therefore infiltration capacity has been reached and the rate cannot increase past this point. This leads to much more surface runoff. When soil is partially saturated then infiltration can occur at a moderate rate and fully unsaturated soils have the highest infiltration capacity.

\section{Organic materials in soils}

Organic materials in the soil (including plants and animals) all increase the infiltration capacity. Vegetation contains roots that extend into the soil which create cracks and fissures in the soil, allowing for more rapid infiltration and increased capacity. Vegetation can also reduce surface compaction of the soil which again allows for increased infiltration. When no vegetation is present infiltration rates can be very low, which can lead to excessive runoff and increased erosion levels. Similar to vegetation, animals that burrow in the soil also create cracks in the soil structure.

d. Microbial Population

This analysis uses MA-11 biological agents that have been tested by the Microbiology Laboratorium of Gadjah Mada University based on Ministerial 
Analysis of The Relationship Between Microbial Activities In Humus Soil Towards Infiltration Rate for Fertility Improvement With Biosoildam Technology for Corn

Plantation

Regulation standards: No 70/Permentan/SR.140/10 2011, includes:

Table 1

Microbes Analysis

\begin{tabular}{llcclc}
\hline No & $\begin{array}{c}\text { Population } \\
\text { Analysis }\end{array}$ & Result & $\begin{array}{c}\text { N } \\
\text { o }\end{array}$ & Population Analysis & Result \\
\hline 1 & Total of Micobes & $\begin{array}{c}18,48 \times \\
10^{8} \mathrm{cfu}\end{array}$ & 8 & $\begin{array}{l}\text { Ure-Amonium-Nitrat } \\
\text { Decomposer }\end{array}$ & Positive \\
\hline 2 & Selulotik Micobes & $1,39 \times 10^{8} \mathrm{cfu}$ & 9 & Patogenity for plants & Negative \\
\hline 3 & $\begin{array}{l}\text { Proteolitik } \\
\text { Micobes }\end{array}$ & $1,32 \times 10^{8} \mathrm{cfu}$ & 10 & $\begin{array}{l}\text { Contaminant E-Coly \& } \\
\text { Salmonella }\end{array}$ & Negative \\
\hline 4 & Amilolitik & $7,72 \times 10^{8} \mathrm{cfu}$ & 11 & $\mathrm{Hg}$ & $2,71 \mathrm{ppb}$ \\
& Micobes & & & $\begin{array}{l}<0,01 \\
\mathrm{mg} / 1\end{array}$ \\
\hline 5 & $\begin{array}{l}\text { N Fixtation } \\
\text { Micobes }\end{array}$ & $2,2 \times 10^{8} \mathrm{cfu}$ & 12 & $\mathrm{Cd}$ & $\begin{array}{l}<0,01 \\
\mathrm{mg} / \mathrm{l}\end{array}$ \\
\hline 6 & Phosfat Micobes & $1,44 \times 10^{8} \mathrm{cfu}$ & 13 & $\mathrm{~Pb}$ & $\begin{array}{c}<0,01 \\
\mathrm{ppm}\end{array}$ \\
\hline 7 & Acidity & 3,89 & 14 & $\mathrm{As}$ & \\
& & & &
\end{tabular}

(resource : (Widiasmadi, 2019)

Its application in Biosoildam is concentrating the microbes into "population media", as a source of soil conditioner for increasing infiltration rates and restoring natural fertility (Nugroho Widiasmadi, 2020).

e. Soil Fertilizer \& Soil Acidity

Microbial activity as a contributor to soil nutrition from the biomass decomposition results can be controlled through the salinity level of the nutrient solution expressed through conductivity as well as other parameters as analog inputs. Conductivity can be measured using EC, Electroconductivity, or Electrical (or Electro) Conductivity (EC) is the nutrients density in solution. The more concentrated the solution is, the greater the delivery of electric current from the cation (+) and anion (-) to the anode and cathode of the EC meter. Thus, it results in a higher EC. The measurement unit of EC is $\mathrm{mS} / \mathrm{cm}$ (millisiemens) (Nugroho Widiasmadi, 2020).

Indications of microbial activity on fertility can be controlled through acidity. The number of nutrients contained in the soil is an indicator of the level of soil fertility due to the activity of biological agents in decomposing biomass. Important factors that influence the absorption of nutrients (EC) by plant roots are the degrees of soil acidity (soil $\mathrm{pH}$ ), temperature $(\mathrm{T})$, and humidity $(\mathrm{M})$. Soil Acidity level $(\mathrm{pH})$ greatly influences the plant's growth rate and development (Widiasmadi, 2019).

\section{Results and Discussion}

a. Design Rainfall and Frequency Duration Intensity (FDI)

The design rainfall intensity was determined using rainfall data from Ngawi 
Station in 2009-2017. Statistical analysis was performed to determine the distribution type used, which in this study was the Log Person III's. Distribution checking on whether rain opportunities can be accepted or not is calculated using the Chi-Square test and the Kolmogorov Smirnov test. Next, the design rainfall intensity is calculated using the mononobe formula.

b. Design Discharge

The design discharge as an MA-11 microbial catalyst uses the rainfall intensity for 1 hour since it is estimated that the most predominant rainfall duration in the area studied is 1 hour. The runoff coefficient for various surface flow coefficients is 0.70 0.95 (Eng \& Dr, 2004), while in this study we use the smallest flow coefficient value, which is 0.70 .

The design discharge has various catchment areas, between $9 \mathrm{~m} 2$ to $110 \mathrm{~m} 2$ with a proportional relationship. The larger the plot, the greater the planned discharge generated as a biohole inflow. The depth of Biohole in the study area in the 25-year return period ranges from $0.80 \mathrm{~m}$ to $1.50 \mathrm{~m}$. The absorption volume will determine the maximum capacity of water contained in the Biohole. The greater the volume of Biohole is, the greater the water container is.

c. Biohole Design

Biohole walls use natural walls with a 0,3-diameter and a 0.8-depth or the storage area of $36 \mathrm{~m} 2$. Organic material (solid pressed corn straw waste) is used as a place for microbial populations/microbial sources. The top is coated with a $5 \mathrm{~cm}$ thick rock which acts as an energy-breaking medium. Thus, when filled with organic material water, it remains stable to maintain the radial spread of microbes.

The Biohole volume capacity for that dimension is $0.0565 \mathrm{~m} 3$, with a catchment of $36 \mathrm{~m} 2$, and the 25 year-discharge $=0.0000841 \mathrm{~m} 3 / \mathrm{sec}$ and will be filled in about 10 to 15 minutes. This figure considers natural resources in the form of rainfall intensity of the study area which adjusted to the spread of microbes. Therefore, the water-emptying phase and the microbial population formulation phase can take place optimally.

If the land is covered by impermeable surfaces, such as pavement, infiltration cannot occur as the water cannot infiltrate through an impermeable surface This relationship also leads to increased runoff. Impermeable areas often have storm drains that drain directly into water bodies, which means no infiltration occurs.

Vegetative cover of the land also impacts the infiltration capacity. Vegetative cover can lead to more interception of precipitation, which can decrease intensity leading to less runoff, and more interception. Increased abundance of vegetation also leads to higher levels of evapotranspiration which can decrease the amount of infiltration rate. Debris from vegetation such as leaf cover can also increase the infiltration rate by protecting the soils from intense precipitation events.

Geomorphology of agricultural land and its surroundings is in the form of humus lands. Humus soil is soil that has organic content as a habitat for soil fertilizing microorganisms so that the soil is rich in nutrients needed by plants. The 
Analysis of The Relationship Between Microbial Activities In Humus Soil Towards Infiltration Rate for Fertility Improvement With Biosoildam Technology for Corn

Plantation

humus found in the soil also makes the soil have the ability to hold water better and protect it from the risk of erosion.

Humus is the soil that consists of a mixture of decomposed organic matter such as dead leaves, twigs, and grass. Content such as aliphatic hydroxides, phenols, and carboxylic acids are substances that exist in humus and are useful for plant fertility. Therefore, in simple terms, humus soil is a type of soil that is formed from the decay of organic matter over a certain period.

The organic material that makes up the hummus comes from organic waste which decomposes and produces small particles with negative charges. Then the negative particles are in charge of absorbing nutrients such as calcium and magnesium. The negatively charged small particles can absorb positively charged nutrients such as calcium and magnesium which are needed by plants. Therefore, in general, humus-rich soils are characterized by dark colors with white spots. The need for humus plants varies from one another. Some plants require a high humus content in the soil to thrive, but some plants can survive in soils with low humus content.

Soil Type Humus According to the process of its formation, humus soil can be divided into several types, namely:

a. Soil is rich in humus due to dust or sand sediment activity

b. Topsoil rich in humus formed from rocks whose surface is overgrown with moss or pioneer plants

c. Humus-rich soil formed from weathering of rocks or plants that decay due to chemical factors, wind, sun, water, and others

The type of humus can also be distinguished from the source of the nutrients present in it. For example, the soil is formed from animal dung, and the soil is made from the remains of dead trees.

Characteristics of Soil Rich in Humus As a fertile land because it is rich in humus, here are the characteristics it has:

1. The soil is dark, black, or brown and there are white spots. It has such a texture because it is formed from the weathering of plants and becomes a source of energy for soil microorganisms, making the soil dark.

2. The soil structure is loose and contains a lot of organic substances

3. High water absorption compared to other soil types. This property is called colloidal and amorphous, where this property is also owned by clay. However, humus soil and clay soil are different, because the topsoil has high water absorption, and the texture is loose and very fertile.

4. Rich in nutrients such as magnesium, calcium, and potassium. In addition, this fertile soil also can multiply the elements in the soil so that if plants grow in the topsoil they will be very fertile.

5. There are soil fertilizing microorganisms

6. Humus-rich soil is flammable

7. Humus-rich soil has a slippery texture when exposed to water

8. Humus-rich soil is a smelly soil 
This soil is soft and easy to work on. This soil type is widely distributed in the Ngawi plains area.

\section{INFILTRATION RATE ON HUMUS SOIL WITH BIOFERTILIZER \\ AT STA A ( WITH BIOFERTILIZER)}
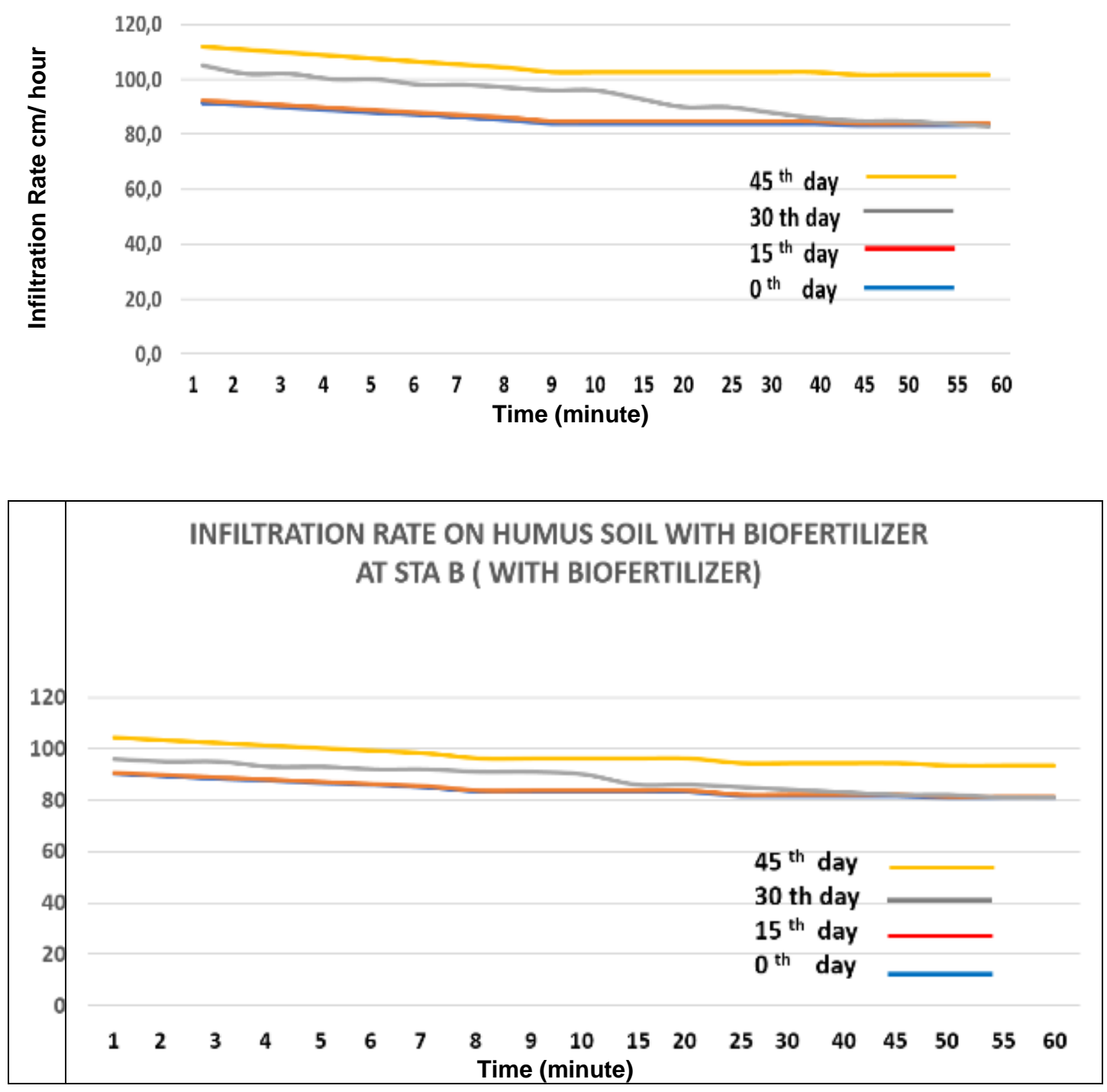
Analysis of The Relationship Between Microbial Activities In Humus Soil Towards Infiltration Rate for Fertility Improvement With Biosoildam Technology for Corn Plantation

\section{INFILTRATION RATE ON HUMUS SOIL WITH BIOFERTILIZER AT STA C ( WITH BIOFERTILIZER)}

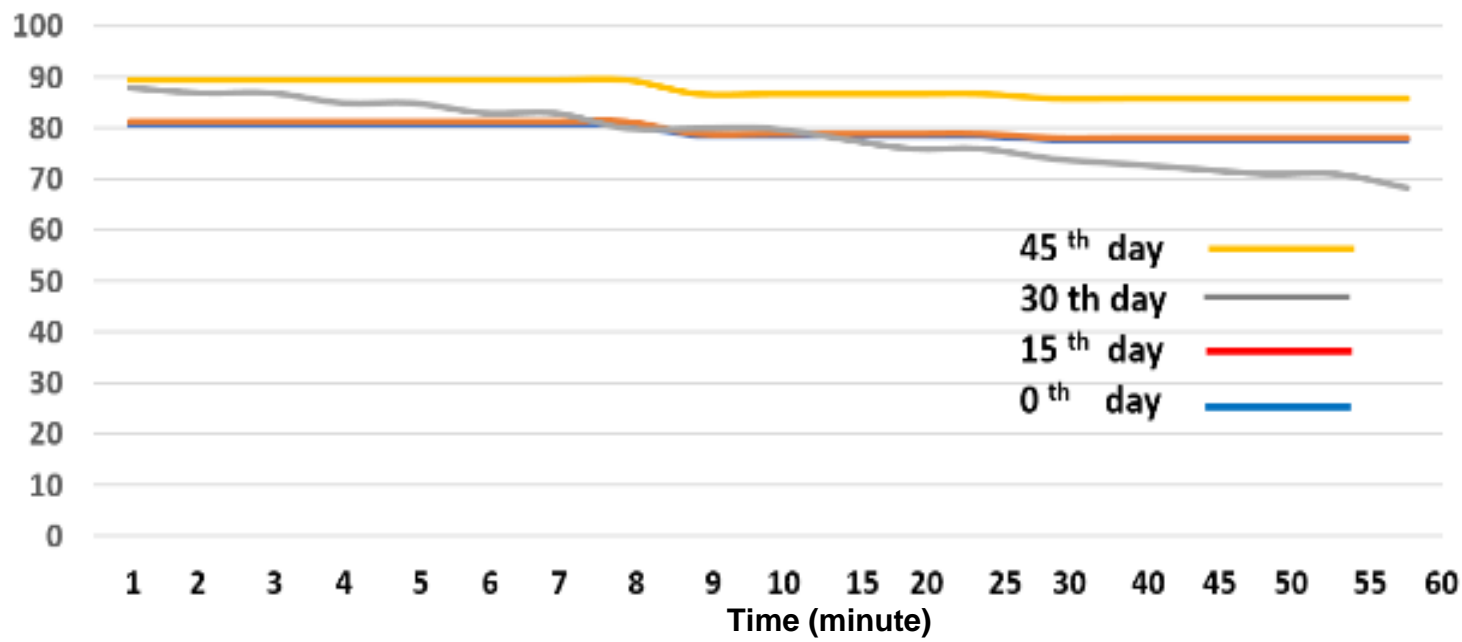

INFILTRATION RATE ON HUMUS SOIL WITH BIOFERTILIZER AT STA A ( WITHOUT BIOFERTILIZER)

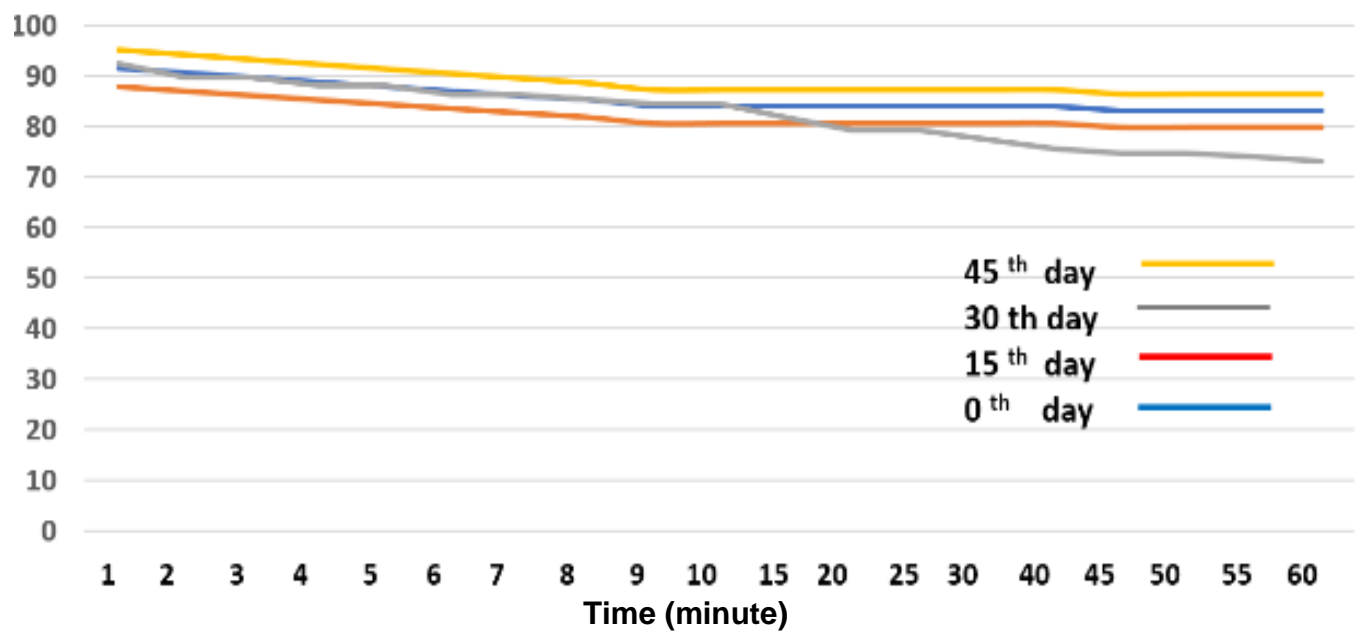

Figure 4

Graph Infiltration rate with Biofertilizer 


\section{INFILTRATION RATE ON HUMUS SOIL WITH BIOFERTILIZER AT STA B ( WITHOUT BIOFERTILIZER)}

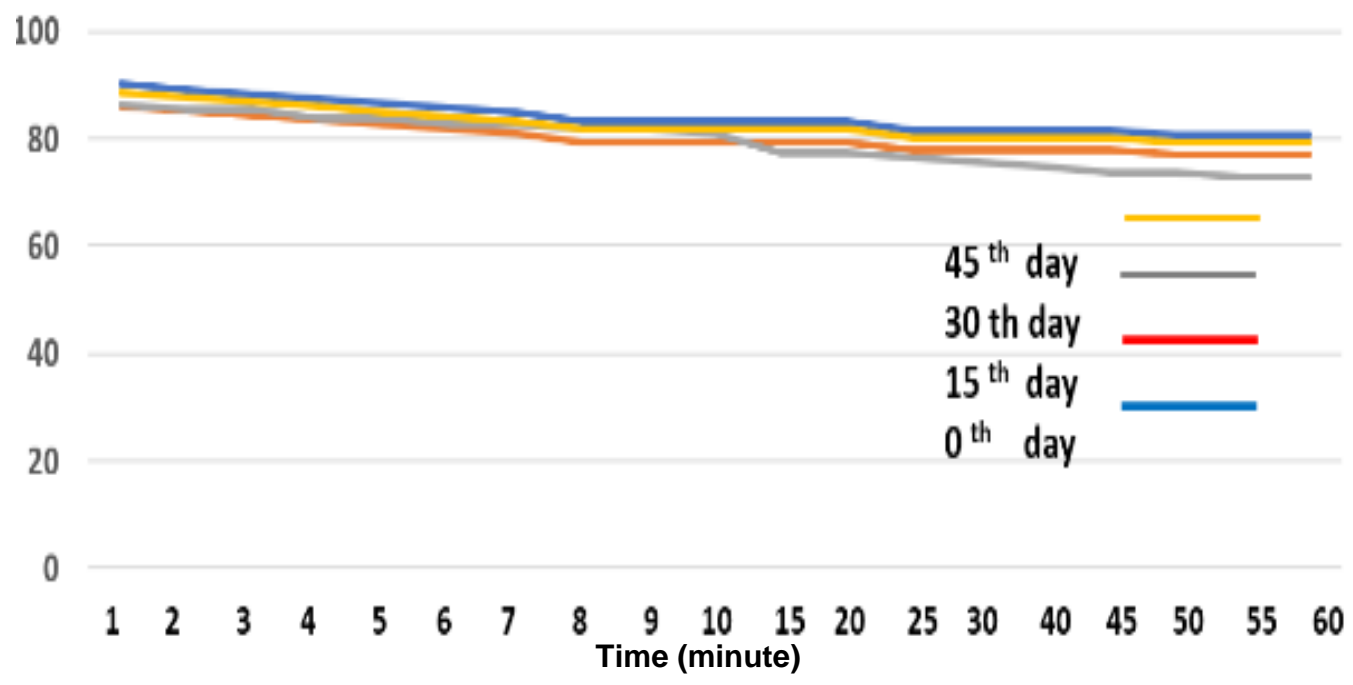

Figure 5

Graph Infiltration rate with Biofertilizer

Technically at the beginning of the spread, the infiltration rate is still relatively small because it only relies on capillary power, but in the following period, the microbial activity that has spread can increase the cavity (porosity), so that the infiltration rate in this advanced period is also greater in Alluvial soils. In addition, the ability of microbes to break down (decomposing) organic material biomass can increase nutrient content in the soil and neutralize soil acidity, along with the increasing infiltration rate.

The above-mentioned soil parameters can be controlled towards the infiltration rate, where the infiltration rate graph shows a constant value at the level of 20 to $40 \mathrm{~cm} / \mathrm{h}$ reached after 30 days with the value ranging from 600 to $700 \mathrm{uS} / \mathrm{cm}$. The biological agent activities in humus soils with infiltration levels will be optimal on the 30th day. 
Analysis of The Relationship Between Microbial Activities In Humus Soil Towards Infiltration Rate for Fertility Improvement With Biosoildam Technology for Corn

Plantation

HUMUS INFILTRATION RATE VS TIME

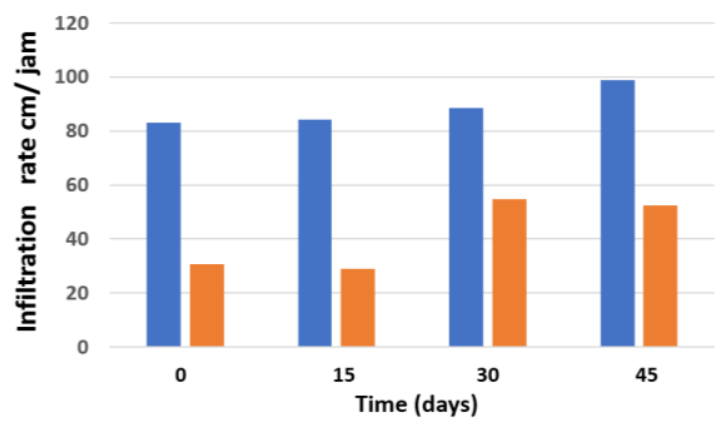

HUMUS INFILTRATION RATE VS RADIUS

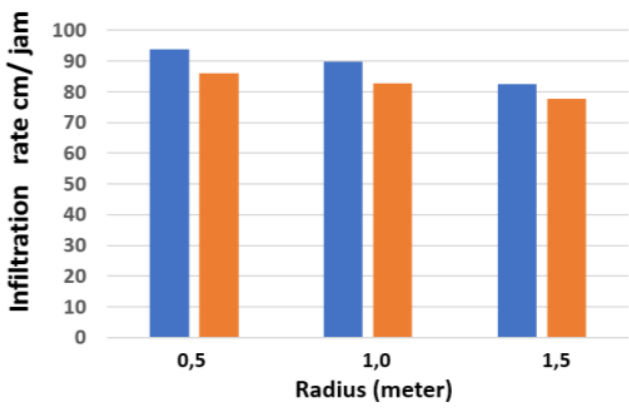

With Biofertilizer Without Biofertilizer

Figure 6

Infiltration Rate vs Time
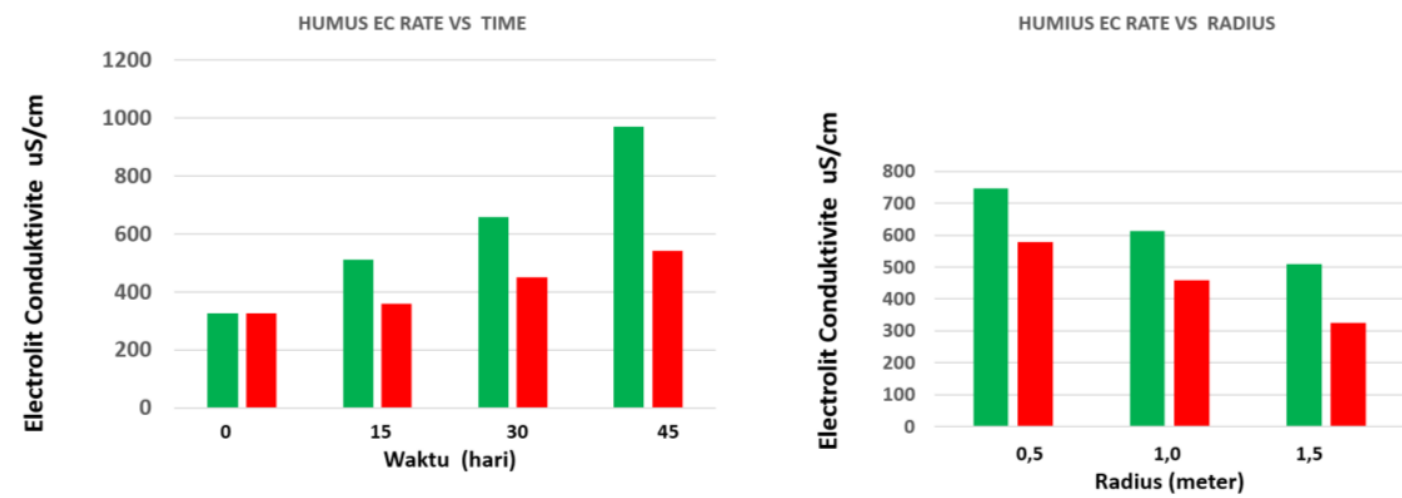

With Biofertilizer Without Biofertilizer

Figure 7

EC Rate vs Time \& EC Rate vs Radius

\section{Conclusion}

Microbial distribution in this case that is the Humus soil layer is quite effective at a maximum radius of 2 meters with a distance between Bioholes of 5 meters and even the spread of the microbes can be even further. The use of microbes in the infiltration well system or the biosolid method as a biological agent is very effective, especially to increase the productivity of barren land into fertile land in a measurable manner so that it does not merely include water. Biosoildam method still needs to be tested for various lands with various rock soil formations so that the relationship between the soil permeability level and the concentration value of microbial population involved for a fertility target of an area to be a productive land is acquired. Biosoildam can be called the "Active Infiltration System" since it involves microbial activities that can be useful for 1). Expanding soil porosity that increases oxygen content as a source of soil health. 
Nugroho Widiasmadi

2). Increasing macro and micro soil nutrient content of the biomass elements that the microbes break down in the distribution zones from the biohole center. 3). Repairing saturated soils that have long been contaminated with chemical fertilizers and pesticides by microbial degradation. 
Analysis of The Relationship Between Microbial Activities In Humus Soil Towards Infiltration Rate for Fertility Improvement With Biosoildam Technology for Corn

Plantation

\section{BIBLIOGRAFI}

Budi, Basuki Setiyo. (2016). Model Peresapan Air Hujan Dengan Menggunakan Metode Lubang Resapan Biopori (Lrb) Dalam Upaya Pencegahan Banjir. Wahana Teknik Sipil: Jurnal Pengembangan Teknik Sipil, 18(1). Google Scholar

Douglas, M. G. (1988). Integrating Conservation Into Farming Systems: The Malawi Experience. Google Scholar

Dr, Nugroho Widiasmadi. (2020). Analysis Of Soil Fertlity And Acidity In Real Time Using Smart Biosoildam To Improe Agricultural Land: International Journal of Research And Analytical Reviews (Ijrar). Volume, 7, 194-200. Google Scholar

Eng, Suripin Dr Ir M., \& Dr, Suripin Ir. (2004). Sistem Drainase Perkotaan Yang Berkelanjutan. Andi Offset, Yogyakarta. Google Scholar

Latifah, Riris Nurul Nurul. (2012). Pemanfaatan Sampah Organik Sebagai Bahan Pupuk Cair Untuk Pertumbuhan Tanaman Bayam Merah (Alternanthera Ficoides). Lenterabio: Berkala Ilmiah Biologi, 1(3), 139-144. Google Scholar

Martha, Luluk. (2018). Studi Resapan Air Hujan Melalui Lubang Resapan Biopori (Lrb) Sebagai Upaya Mereduksi Beban Drainase Di Universitas Islam Negeri Sunan Ampel Surabaya. Uin Sunan Ampel Surabaya. Google Scholar

Rochim, Faidloh Nur, \& Syahbana, Joesron Alie. (2013). Penetapan Fungsi Dan Kesesuaian Vegetasi Pada Taman Publik Sebagai Ruang Terbuka Hijau (Rth) Di Kota Pekalongan (Studi Kasus: Taman Monumen 45 Kota Pekalongan). Teknik Pwk (Perencanaan Wilayah Kota), 2(3), 314-327. Google Scholar

Santosa, Slamet. (2018). Effect Of Fruits Waste In Biopore Infiltration Hole Toward The Effectiveness Of Water Infiltration Rate On Baraya Campus Land Of Hasanuddin University. Journal Of Physics: Conference Series, 979(1), 12037. Iop Publishing. Google Scholar

Sunjoto, S. (2011). Teknik Drainase Pro-Air. Yogyakarta: Fakultas Teknik Universitas Gadjah Mada. Google Scholar

Sutanto. (2012). Desain Sumur Peresapan Air Hujan. In Laporan Penelitian. Yogyakarta: Fakultas Geografi Universitas Gadjah Mada. Google Scholar

Widiasmadi, Nugroho. (2019). Peningkatan Laju Infiltrasi Dan Kesuburan Lahan Dengan Metode Biosoildam Pada Lapisan Tanah Keras Dan Tandus. Prosiding Snst Fakultas Teknik, 1(1). Google Scholar

Widiasmadi, Nugroho. (2020a). Analisa Elektrolit Konduktifitas \& Keasaman Tanah Secara Real Time Menggunakan Smart Biosoildam. Prosiding Seminar Nasional Nciet, 1(1), 11-24. Google Scholar 
Widiasmadi, Nugroho. (2020b). Soil Improvement And Conservation Based In Biosoildam Integrated Smart Ecofarming Technology (Applied In Java Alluvial Land And Arid Region In East Indonesia). Int J Innov, 5(9). Google Scholar

Widyastuti, Sri. (2013). Perbandingan Jenis Sampah Terhadap Lama Waktu Pengomposan Dalam Lubang Resapan Biopori. Waktu: Jurnal Teknik Unipa, 11(1), 5-14. Google Scholar

Yohana, Corry, Griandini, Dientje, \& Muzambeq, Said. (2017). Penerapan Pembuatan Teknik Lubang Biopori Resapan Sebagai Upaya Pengendalian Banjir. Jurnal Pemberdayaan Masyarakat Madani (Jpmm), 1(2), 296-308. Google Scholar

Zhanbin, Huang, Lun, Shan, Suiqi, Zhang, \& Pute, Wu. (1997). Action Of Rainwater Use On Soil And Water Conservation And Agriculture Sustainable Development [J]. Bulletin Of Soil And Water Conservation, 1. Google Scholar

\section{Copyright holder:}

Nugroho Widiasmadi (2021)

First publication right:

Syntax Literate: Jurnal Ilmiah Indonesia

This article is licensed under:

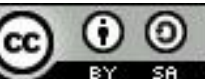

